\title{
Information technology students’ beliefs on industry certifications
}

\author{
M. Koivisto* \\ * Mikkeli Universtity of Applied Sciences
}

\begin{abstract}
The common challenge of Information Technology (IT) educators all over the world is to design a curriculum that is relevant to the evolving needs of the industry and society in general. One method many universities have started to use is to embed industry certifications to their curriculums. In this paper IT students' beliefs on these certifications are analysed. The aim of the study is based on the following research question: How taking part on the certification training and exams changes students' beliefs on industry certificates, do students value the industry certification similarly today than earlier and do students see that the industry certificates are more important in some job roles than in others. The results of the study suggest that students have realistic idea what industry certificates are and where they are needed. Although the ever-increasing popularity of industry certificates have maybe somewhat decreased their value, students still believe that they are valuable especially when entering the labour markets. Therefore, the results of the study suggest that industry certifications should have a role in higher education curriculums also in the future.
\end{abstract}

Keywords: Industry certification; higher education; student beliefs

\section{Introduction}

The role and importance of Information Technology (IT) industry certification has been a topic amongst higher education institutions like colleges and universities for more than twenty years. Multiple stakeholders like certification providers, employers as well as some scholars have claimed that professional certifications are vital indicators of professionalism (Teske \& Philips, 2010; Chilton et al., 2010) and majority of hiring managers use professional credentials, such as industry certification, to identify properly skilled IT candidates (Microsoft, 2012). Although a formal degree and earlier work experience are essential for job applicants, industry certifications can give them a competitive advantage and set them above the competition.

The focus of the paper is on IT students' attitudes towards industry certifications and it is analysed from three different perspectives. First, possible changes in students' beliefs on industry certification is analysed by comparing opinions of students in different grades toward industry certificates. Because the first year students have not yet done any certification exams unlike the older students, the first research question of the paper is: Does participation on the certification training and exams change students' beliefs on industry certificates?

Second, the effect of time on certification beliefs is analysed also by comparing the current results against a study conducted in 2008. This lead us to the second research question of the study: Do students value the industry certification similarly today than earlier? The motivation of this question is that some critics (e.g. Snyder, 2012; Cinalli, 2015) have suggested that the increased popularity of IT certification programs has decreased the value of the certificates.

Third, IT students entering a labour market can select different careers and job roles (including e.g. a network or security professional, project manager, software developer, and database administrator). These tasks have different kinds of 
requirements and skills. Thus the third research question of the paper is: Do students see that the industry certificates are more important in some job roles than in others?

The structure of the paper is as follows. The next chapter of the paper is a short literature review on industry certificates and their believed benefits. After that research method and data collection process of the reported study are described. The results of the study are then presented and discussed and the paper ends with a conclusions section.

\section{Literature review}

Industry certification programs organized by vendors or professional societies focus on developing the skills and knowledge of a person to perform a job or task. The first corporate vendor certification (Certified Novel Engineer, or CNE) was issued already in 1989 (Adelman, 2000) and after that the number of companies and industry or professional associations offering them has increased dramatically. Lloret et al. (2013) distinguished three main types of certifications:

- Profession-wide certifications which do not depend on the company's definition of a certain job and they provide a professional knowledge and experience to the persons.

- Internal certifications, which are internal of a corporation, and can only be achieved by their personnel.

- Product or technology certifications. This kind of certificates have been very common in IT industry where personnel should be certified on a specific version of software or hardware.

Today certification is a big industry in which the leading companies deliver more than a ten million tests each year (PearsonVUE, 2015; Prometric, 2015). However, the benefits of certifications goes far beyond the testing centres. According to Randall \& Zirkle (2005) embedded certification programs offer benefits to multiple stakeholders including students, employers, vendors and educational institutions. Students can use the certificates and related skills to get employment. Employers can use certifications as a way to differentiate qualified candidates in a sea of resumes. Educational institutions gain access to ready-made, industry-sponsored IT curriculums that are responsive to workforce needs. A vendor benefits by gaining trained workers to support their product, service, or technology.

Although certifications benefit vendors and employers, the largest benefactors of IT certifications are the IT professionals. Some scholars suggest that certification particularly benefits inexperienced employees, who can market themselves using IT certification as a substitute for job experience. (Hitchcock, 2006). Kabia et al. (2013) however pointed out that this assumption is erroneous. They emphasized that experience does not necessarily imply skill or knowledge but the value of the certifications is in a person's ability to apply the gained knowledge and competency.

Multiple studies suggest that certifications do not only increase the chances of job acquisition, but it also, increases pay. For example, a survey conducted amongst 700 networking professionals concluded that after certification acquisition, 40 percent earned more pay and increased an average of ten percent (Bort, 2011).

Reinicke \& Janicki (2013) analysed the importance of certifications across areas of Information Systems. They found out that certification were far more popular in some 
jobs than in others. For example, 69 per cent of professionals working in networking or security have a certification. Similar high percentage was measured among IT project managers (63\%). On the other hand, in software development and database administration the percentage were remarkably lower (14\% and $20 \%$ respectively).

\section{Methods}

In this study IT students' beliefs on industry certifications was collected with a simple questionnaire. The questionnaire was distributed to IT students of a small Finnish university. The university has embedded two Cisco professional training courses (CCNA and CCNA Security) and three Microsoft MTA certifications (Networking fundamental, Security fundamentals and HTML5 to its curriculum). Because the CCNA course is divided to four parts the total number of compulsory certification tests in the curriculum is eight.

The target group of the survey was students in different grades and phases of their studies. This selection gave a possibility to analyse how student attitudes change over time. The first year students had not done any certification tests unlike the students on higher grades. The second year students had already done three or four tests and they had certification training during the data collection time. The third and the fourth year students had done all or almost all compulsory certification exams already (5 - 8 tests).

The total number of students was 49 (36 male and 13 female) and the distribution of the students for the classes is shown in Table 1 below. The third and fourth year students were combined into a single group because there are no compulsory certification exams during the fourth year.

Table 1. Number of students.

\begin{tabular}{|c|c|c|c|}
\hline & Male & Female & Total \\
\hline First year students & 15 & 3 & 18 \\
\hline Second year students & 10 & 5 & 15 \\
\hline Third and fourth year students & 11 & 5 & 16 \\
\hline
\end{tabular}

The data was collected with a paper questionnaire during the normal lecture times. The questionnaire contained the following sections: Background information, completed industry certifications or trainings, and students' general and sector specific beliefs on certifications. The general belief questions used in the survey were identical to questions used by Hunsinger \& Smith (2008) in their study on factors that influenced information system undergraduates to pursue IT certifications. The use of same questions gave a good possibility to compare our results against earlier findings.

\section{Results}

The students'general perceptions of outcomes of IT certification was captured through nine positive statements. These statements as well as results for different student groups are shown in Table 2 . The result are surprisingly similar for all grades. There is no statistical difference (p. <05) in any dimension between freshmen and older student groups. 
Table 2. Averages and standard deviations of students' general beliefs. (Likert scale: $7=$ strongly agree, $1=$ strongly disagree).

\begin{tabular}{|l|c|c|c|}
\hline I believe that certifications & $1^{\text {st }}$ year & $2^{\text {nd }}$ year & $\begin{array}{c}3^{\text {rd }} \text { and } \\
4^{\text {th }} \text { year }\end{array}$ \\
\hline Would increase my likelihood of getting hired by an employer. & $\begin{array}{c}6.07 \\
(0.64)\end{array}$ & $\begin{array}{c}6.30 \\
(0.62)\end{array}$ & $\begin{array}{c}5.64 \\
(0.94)\end{array}$ \\
\hline Would differentiate me from other job candidates applying for a & $\begin{array}{c}5.60 \\
(0.96)\end{array}$ & $\begin{array}{c}5.80 \\
(1.12)\end{array}$ & $\begin{array}{c}5.64 \\
(0.84)\end{array}$ \\
position. & 5.67 & 5.70 & 5.64 \\
& $(0.82)$ & $(1.06)$ & $(0.62)$ \\
\hline Would increase my marketability to potential employers. & 5.67 & 5.90 & 5.91 \\
& $(1.23)$ & $(1.39)$ & $(0.76)$ \\
\hline Would increase my qualifications for a job. & 5.93 & 6.20 & 6.27 \\
& $(1.17)$ & $(0.58)$ & $(0.83)$ \\
\hline Would give me an advantage over other job candidates who do & 4.93 & 5.40 & 5.00 \\
not hold an IT certification. & $(1.44)$ & $(1.31)$ & $(1.29)$ \\
\hline Would increase my helpfulness to a company. & 4.87 & 5.60 & 5.18 \\
& $(1.24)$ & $(1.07)$ & $(0.90)$ \\
\hline Would make me more valuable to a company. & 4.93 & 4.80 & 4.55 \\
& $(1.31)$ & $(0.94)$ & $(0.95)$ \\
\hline Would help me to make more money than a similar job candidate & 4.93 & 5.20 & 4.82 \\
who does not hold an IT certification. & $(1.12)$ & $(0.94)$ & $(1.28)$ \\
\hline Would help me to earn more respect. & &
\end{tabular}

In an earlier study over $90 \%$ of respondents replied with some measure of agreement (somewhat agree, agree, or strongly agree) to all nine statements used also in our study (Hunsinger \& Smith, 2008). Our results are compared against these earlier findings in Table 3.

Table 3. Summaries of the results in two studies.

\begin{tabular}{|l|c|c|c|c|c|c|}
\hline \multirow{2}{*}{ I believe that certifications } & \multicolumn{3}{|c|}{ Our results (N=49) } & \multicolumn{3}{c|}{ Hunsinger\&Smith (N=120) } \\
\cline { 2 - 7 } & $\begin{array}{l}\text { Percent } \\
\text { agree }\end{array}$ & $\begin{array}{l}\text { Percent } \\
\text { neutral }\end{array}$ & $\begin{array}{l}\text { Percent } \\
\text { disagree }\end{array}$ & $\begin{array}{l}\text { Percent } \\
\text { agree }\end{array}$ & $\begin{array}{l}\text { Percent } \\
\text { neutral }\end{array}$ & $\begin{array}{c}\text { Percent } \\
\text { disagree }\end{array}$ \\
\hline $\begin{array}{l}\text { Would increase my likelihood of } \\
\text { getting hired by an employer. }\end{array}$ & 93.9 & 6.1 & 0.0 & 97.5 & 2.5 & 0.0 \\
\hline $\begin{array}{l}\text { Would differentiate me from other job } \\
\text { candidates applying for a position. }\end{array}$ & 87.8 & 6.1 & 6.1 & 95.9 & 1.1 & 0.0 \\
\hline $\begin{array}{l}\text { Would increase my marketability to } \\
\text { potential employers. }\end{array}$ & 89.8 & 10.2 & 0.0 & 95.8 & 4.2 & 0.0 \\
\hline $\begin{array}{l}\text { Would increase my qualifications for a } \\
\text { job. }\end{array}$ & 91.8 & 2.0 & 6.1 & 95.8 & 2.5 & 1.7 \\
\hline $\begin{array}{l}\text { Would give me an advantage over other } \\
\text { job candidates who do not hold an IT } \\
\text { certification. }\end{array}$ & 93.9 & 4.1 & 2.0 & 95.0 & 5.0 & 0.0 \\
\hline $\begin{array}{l}\text { Would increase my helpfulness to a } \\
\text { company. }\end{array}$ & 71.4 & 12.2 & 16.3 & 92.6 & 5.0 & 2.4 \\
\hline $\begin{array}{l}\text { Would make me more valuable to a } \\
\text { company. }\end{array}$ & 77.6 & 14.3 & 8.2 & 92.6 & 5.8 & 1.6 \\
\hline $\begin{array}{l}\text { Would help me to make more money } \\
\text { than a similar job candidate who does } \\
\text { not hold an IT certification. }\end{array}$ & 59.2 & 32.7 & 8.2 & 90.0 & 7.4 & 1.6 \\
\hline Would help me to earn more respect. & 59.2 & 32.7 & 8.2 & 81.0 & 16.5 & 2.5 \\
\hline
\end{tabular}

Our results suggest that students still believe in positive outcomes of the certificates but our results are lower in all cases. The noticeable difference can be found in four last statements related to personal helpfulness, value to a company, higher earnings and respect. 
According to our survey students believed that certifications are not equally important in all sectors of information technology. They found certificates most valuable in network and security related jobs. For software developers certifications were considered to be less important. Descriptive statistics are shown in Table 4.

Table 4. Believed value of certification in different job roles.

(Likert scale: $7=$ strongly agree, $1=$ strongly disagree).

\begin{tabular}{|l|c|c|c|c|}
\hline Job type & Mean & SD & $\begin{array}{c}95 \% \text { CI } \\
\text { lower bound }\end{array}$ & $\begin{array}{c}95 \% \text { CI } \\
\text { upper bound }\end{array}$ \\
\hline Networking professional & 6.42 & 0.52 & 6.28 & 6.55 \\
\hline Security professional & 6.22 & 0.68 & 6.04 & 6.40 \\
\hline Project manager & 5.17 & 0.95 & 4.91 & 5.42 \\
\hline Software developers & 4.94 & 1.16 & 4.64 & 5.25 \\
\hline Database administrators & 5.58 & 1.01 & 5.31 & 5.85 \\
\hline
\end{tabular}

\section{Discussion}

This discussion section is organized according to the three research questions stated in the introduction.

\section{Research question 1: Does participation on the certification training and exams change students' beliefs on industry certificates?}

Our results are clearly suggesting that students' beliefs remain very stable before, during and after participating industry certification training and exams. We believe that this indicates that students have a good understanding of certification and therefore they do provide neither positive nor negative surprises to them. The certifications are essential part of current IT environment and according to our study students are aware of this.

\section{Research question 2: Do students value the industry certification similarly today than earlier?}

The finding of the study indicated that students still believed that certificates can help them to get a job and differentiate them from other applicants. When asked about various positive outcomes that could await them as a result of holding an IT certification, the average score was 5.47 (in Likert scale: $7=$ strongly agree, $1=$ strongly disagree).

When comparing our results against an earlier study we found out that in our study the number of students with some measure of agreement (somewhat agree, agree, or strongly agree) was lower in all nine statements and the average difference was 12.4 per cent. In some areas (like helpfulness to the company, higher earnings and respect) our results were remarkably lower (21.2, 30.8 and 21.8 respectively) than what was reported in 2008.

What could be the reasons for this development? It is too early to state some final conclusions but the popularity of industry certifications and increased number of institutions using them might have somewhat decreased the perceived value of industry certificates among students. 


\section{Research question 3: Do students see that the industry certificates are more important in some job roles than in others?}

Our results are indicating statistically significant differences between students' beliefs on importance of certifications in different jobs. They believed that certificates are most valuable for network and security specialist but less important for project managers, database administrators and especially for software developers. These results supports the findings of Reinicke \& Janicki (2013) although they pointed out even bigger differences between career paths.

\section{Conclusions}

This paper focused on IT students' attitudes towards industry certifications. The results of the study are suggesting that IT students' beliefs on professional certifications are realistic and therefore there is no statistically significant change during their study time. The increased number of different kinds of certificates and wide adaptation of certifications to university curriculums may have decreased the value of certifications but students still see them especially important when applying for a new job. Students seem to have also a quite clear idea in which jobs the certificates are almost a requirement and where they are currently so strongly required. This information is a vital when students are personalising their study plans according to their future career paths.

Our study has its limitations. First of all the study was conducted only in one university and the results cannot be generalized to all countries and cultures. Second, the sample size was quite small and discussion was limited only to the students' beliefs. Therefore, more studies are still needed to analyse the role of industrial certificates in academic education. For example, the employers' opinion about advantage of certifications in recruitment processes as well as professors' and teachers' views and best practices on embedding industry certifications to academic studies should be analysed.

Even with its limitations, the findings of the study clearly pointed out that students have positive attitude towards industry certifications and therefore industry certifications should have a role in higher education curriculums also in the future.

\section{References}

Adelman, C. (2000). A parallel universe, expanded: Certification in the information technology guild. Retrieved January 5, 2015, from Internet: http://www.aahe.org/change/paralleluniverse.htm

Bort, J. (2011). Will IT certs get you jobs and raises? Survey says yes. Network world, Nov 14.

Chilton, M. A., Hardgrave, B. C., \& Armstrong, D. J. (2010). Performance and strains levels of IT workers engaged in rapidly changing environments: A person-job fit perspective. ACM SIGMIS Database archive. 41 (1), 8-35

Cinalli, F. (2015). Are IT Certifications losing their value? Retrieved April 16, 2015 from Internet: http://federicocinalli.com/ 
Hitchcock, L. (2006). Methodology in computing education: a focus on experience, Proceedings of the 19th Annual Conference of the National Advisory Committee on Computing Qualifications. Wellington, New Zealand

Hunsinger, D. S., \& Smith, M. A. (2008). Factors that Influence Information Systems Undergraduates to Pursue IT Certification. Journal of Information Technology Education, 7, 247-265.

Kabia, M., Oni, O., \& Booher, L. (2013). Information Technology Certification as a Predictor of Job Performance. Journal of Leadership and Organizational Effectiveness, 1, (1), 15 - 32.

Lloret, J., Vela. M., Plaza E., de Soria, J., \& Pena-Ortiz, R. (2013). Industry Certificate Courses Enhance University Experts and Masters. Proc. of $4^{\text {th }}$ UNIVEST Conference, Girona.

Microsoft. (2012). Microsoft Certification Program Satisfaction Study.

PearsonVUE. (2015) Discover Pearson VUE. Retrieved January 20, 2015 from http://home.pearsonvue.com/About-Pearson-VUE/Discover-Pearson-VUE.aspx.

Prometric. (2015) About Prometric. Retrieved January 20, 2015 from https://www.prometric.com/en-us/about-prometric/pages/prometric-advantageoverview.aspx.

Reinicke, B. A. \& Janicki, T. (2013). Who Needs Certifications? A Survey of Certifications in the IT Industry. Proc. of the Information Systems Educators Conference, San Antonio, Texas, USA

Randall, M. H., \& Zirkle, C. J. (2005). Information Technology Student-Based Certification in Formal Education Settings: Who Benefits and What is Needed. Journal of Information Technology Education, Vol. 4.

Shaeiwitz, J.A., \& Turton, R. (2003). Educating chemical engineers in product design. International Journal of Engineering Education, 19, 153-157.

Snyder, B. (2012). The IT certs that no longer pay extra -- and the new skills that do. InfoWorld.

Teske, M. \& Philips P. (2010). Microsoft Technology Associate Student study guide 98-367.

Van Vugt, M., Hogan, R., \& Kaiser, R. B. (2008). Leadership, followership, and evolution: Some lessons from the past. American Psychologist, 63(3), 182-196. 